\title{
Assessment Improvement Proposal for the American School System of the 2020's
}

\author{
Rebecca Reynolds \\ Grand Canyon University \\ Saint Xavier University \\ Trinity Christian College
}

\begin{abstract}
America's educational standing is slowly falling in the world's education rankings. America is also one of the few countries where assessment and core educational requirements are not the same through-out the country, leaving room for complete validity with-in the American system of education. This project sought to describe, and present a possible solution to the issues of the American educational system's lack of validity and the current state of falling. The appropriateness and validity of a country's educational system assessment format profoundly impacts the success rate of post-secondary teaching and learning.
\end{abstract}

Keywords: assessment, validity, consistency, collaboration, non-bias, fairness

\section{PROBLEM STATEMENT}

In America, there is not a nationwide credentialed, required format, curriculum or assessment (Frye, 2015). The federal government outlines a general minimum requirement, such as required bench mark measurements. These minimum benchmarks are delegated to the states, where every state then writes their own interpretations and passing those down to the local ordinances, where once again more interpretations are written and delegated to the schools, where they are once again, interpreted and delegated to the teachers, who may or may not change the requirements again (Murphy, 2014). The American "system" can change the format on average five times before the requirements are used in each classroom. This leaves little room for complete validation. Validation can only happen with consistency (Cambridge Assessment, 2020). Improvement in testing objectives, reasons, formats, differentiation and use of results, all need to be taken into consideration; and how to create valid assessment formats country wide.

\section{NON-BIAS EQUITY IN ASSESSMENT}

Assessment consistency can only happen with non-bias equity (Reynolds, 2012) throughout the country's school systems. Current curriculum and assessment are not always intertwined, leaving more gaps in measurement. "In terms of assessing student learning, the field has been largely quiet when it comes to issues of equity" (Montenegro, E., Jankowski, N. A., 2017, Occasional Paper No. 29). Little if no conversation is happening between law makers, curriculum designers, assessment designers and educators. Ironically, communication is vital to the success and validity of America's curriculum and assessment designs. Montenegro \& Jankowski (2017) stated: 
Little of the conversation thus far has focused on the connection points between demonstration of student learning and issues of equity. Instead, assessment has remained largely unchanged in regards to inclusivity, and little urgency has been given to ensuring that students are provided with just and equitable means to demonstrate their learning (p.5).

Thus, leaving many children out of the curriculum-assessment cycles. The inconsistency includes but is not limited to, large differences between needed educational supplies per child, money spent on teacher training, incredible differences in class sizes, community resources for those in need and many others. Across the board inconsistent educational services favors those who are wealthy taking educational funds from local taxes, instead of a nationwide tax to provide for all children the same nationwide (NCES, 2020). This lack of assessment design, conversation, and financial equity leads to bias, and poor validity in assessment results (Viswanathan M, Berkman ND, Dryden DM, et al., 2013).

\section{Nation-wide Assessments}

To gain an improved valid nationwide measurement of assessment, America needs to endorse and adopt a complete, bias-free, nationwide assessment format, that follows a child from early childhood through high school graduation. This format will show each child's progress through chronological measures and documentation. "The United States does not use written or oral national examinations to determine graduation from school or access to further studies, and there is no national curriculum on which to base such examinations" (United States Department of Education, 2008, para. 1). But instead, "scale scores, derived from student responses to assessment questions, summarize the overall level of performance attained... Scale scores for individual students are not reported, but summary statistics describing scale scores for groups of students (demographic, gender, race/ethnicity, etc.) are reported" (US Department of Education, 2019, para. 2). Although reporting groups of assessment results are an important measure, the reporting must be done in a cumulative, chronological and methodical format that demonstrates the growth and improvement of each student, and school as a whole. The "scores are developed independently for each subject, results cannot be compared across subjects" (US Department of Education, 2019, para. 2). This process leaves many questions unanswered and gives no motive for moving forward into an improved upon assessment format that contains a cumulative whole measuring of America's progress.

A form of assessment readily available in the Early Childhood Field of education, is portfolio assessment. "Portfolios, containing a variety of different work products (... writing samples, labelled diagrams pictures, checklists, audio files) ... a good way for students to demonstrate their developing knowledge and skills...used as an alternative to summative assessments based on final written examinations" (Frankfort International School, n.d. para 15). Each child beginning in their early education years, can be assessed using a portfolio that moves with each child to each grade level as the child progresses through the grades. When using the same organizational format for each grade level, using work samples, developmental and educational checklists, observational assessment, and other formatted documents throughout each portfolio, validity can be found along with each child's growth patterns and educational levels progressed through (Knauf, 2017).

On the for-front of non-bias assessment are questions about assessments for English Language Learners (ELL). For example, how can non-English speaking students be assessed bias-free (Department of Education and Early Childhood Development, 2014)? Should English assessments be used, or should the assessments be given in the student's primary language? "Providing ESL" (English as a Second Language) "students with a different way to demonstrate knowledge and skills (i.e. alternative assessment) is often" thought of as, "the only sensible choice for those with low English proficiency. Having them do the same assessment as the native speakers in the class can be a demoralizing experience...particularly if they understand the content but do not yet have" ability "to articulate this understanding" (Frankfort International School, n.d. para 13). With this information an assessment translated into the home language of each student, as well as an English proficiency assessment, each new term can demonstrate the student's individual progress. Also, by taking away the stress of testing ESL students, giving them an option to test 
separately from English-speaking students (Wilang, J. D., \& Singhasiri, W., 2017)., or having assistance catered to their individual needs, can help these students feel more secure thus helping each one to succeed.

Measuring growth in English skills for both ELL's and English-speaking students need to assess each student for growth, instead of teaching children to pass any specific test. "English language learners (ELL's) are the fastest growing subgroup in the nation" (University of California, 2008, p. 1). As this group of children grows, so does the need for educators who can communicate with the children and their families. Currently the majority of ELL students are Spanish speaking, creating a need for teachers who can speak both Spanish and English. However, "Not only is the size of the ELL population growing, but the diversity of these students is becoming more extensive. Over 400 different languages are reported among these students;" (University of California, 2008, p 1), creating a real educational need for non-biased assessment. Many challenges are faced by these families and children; for example, "The sizable ELL population typically fails to meet the proficient level in academic standards, and the academic gap between this group and the non-ELL population is considerable" (University of California, 2008, p. 2). Even with the beginning of the first American tests, bias was intentional, "the idea of a monolingual society inspired the creation of standardized tests in the nation in which English language proficiency at the listening, speaking, reading, and writing level is assumed and expected along with knowledge of culture and societal rules" (Marin, 2015).

The lack of "understanding and promoting ELLs' academic achievement has posed a challenge" (Marin, 2015, p. 24) not only for the ELL students, but also for the assessment results of every school that hosts non-English speaking children. Not having the appropriate tools in place to assist in non-bias assessment of ELL children, a standard of low scores has been established. This new standard has created an environment where "... the nation have placed the ELL subgroup at-risk of failing" (Marin, 2015, p. 24), and has placed failing assessment scores for the school as a whole, in which English speaking children attend. This assessment situation creates an assessment failure for both English speaking and ELL students, leading to the closure of failing schools that may be assisted by providing mentoring in areas of need, assessment of areas of need, and by providing correct services to the children instead of closing.

\section{EDUCATIONAL PROVISIONS}

By providing what individual children need in both general education and special education, instead of closing down failing schools, we can prevent the closures of schools. Communities around each school is a base for where children learn their life skills and find their safety nets. Children can be better served with their own community supports and differentiation "Differentiation is a way of teaching", or "pedagogy... It asks teachers to know their students well so they can provide each one with experiences and tasks that will improve learning" (Robb, 2019, para. 1). With the improved learning, and knowledge that teachers are there to help, assessment will locate areas of need while measuring growth.

In today's classroom there are several formats that can be used to assess and gain a complete picture of any needs of the individual children and school as a whole; with "Ongoing, formative assessment" for example, "Teachers continually assess to identify students' strengths and areas of need so they can meet students where they are and help them move forward. By understanding the specific needs of each student, and gaining the "Recognition of diverse learners", we know that "The students we teach have diverse levels of expertise---Ongoing assessments enable teachers to develop differentiated lessons that meet every students' needs" (Robb, 2019, para. 2).

There are several different formats that can be used to meet student's needs. At times this may take some creativity. Group work for example, can help students to collaborate "in pairs and small groups whose membership changes as needed. Learning in groups enables students to engage in meaningful discussions and to observe and learn from one another" (Robb, 2019, para. 2). This can include a planned method of using peer pressure to entice children to be interested in a lesson. Group work can be used as an assessment tool; simply with the use of a checklist and observation for example, you can check off items such as "taking turns", "talking in turn", "listening skills", etc., once observed. 
Give teachers and children choices, "in their reading and writing experiences and in the tasks and projects they complete. By negotiating with students, teachers can" choose "motivating assignments that meet students' diverse needs and varied interests... you can see that differentiating instruction asks teachers to continually strive to know and to respond to each students' needs to maximize learning" (Robb, 2019, para. 5). Using a formatted assessment and curriculum that offers choice, teachers feel supported and children are empowered. The reading material and instruction available should be leveled and gradual, giving a valid format for passing through each level. Writing should also be leveled to give validity, and assessed with working examples chronologically filed into a portfolio showing growth and progression, along with any reading assessments.

Another area that needs to be given provision for academics and assessments include mental health services. "...to provide improved coordination in... mental health services to youth, Illinois developed the Screening, Assessment and Support Services (SASS)...". The... "Children's Mental Health Act of 2003 (pdf) (html) (Public Act 93-0495)" was signed into law (Illinois Health, 2019, para. 1). Mental health services need to be assessed on a regular basis and provided to every family member of the students serviced. Once passed the law HR 1109, Mental Health Services Act of 2019 will help the children's lives at school and at home; this law outlines a format to fund and provide for student mental health services (Congress.gov, 2019-2020), an area that is not well serviced by most American schools.

Family needs should be given provision for academics and assessments. "Whole family assessments provide the opportunity to bring together individual assessments to provide an overview of family strengths, risks, relationships and needs" (Kendall, Rodger, Palmer, 2010). Invaluable information that can lead to help for individual children, can be found in assessing family needs. Forming a family needs assessment on each family annually can lead to greater success in the classroom. Being "Family-centered" is "essential when communicating assessment results" no matter when "conversations about the child's performance should focus on the child's strengths as well as his/her needs or challenges" (John's Hopkins University, 2011, para.1).

Assessing the educational needs of each family, and helping to meet the needs assessed, can make a significant difference in the classroom for both students and teachers. This is obviously a topic that would benefit from intensive research. However, "A teacher may not understand why a parent is fighting or disagreeing with the course of treatment; meanwhile, a parent may still not entirely understand or accept what is different about their child" (Gryphon House, 2016, para. 2) if special services are needed. When the school uses the free, federally-supported resources that "are available to help families learn about child development and help them to support their child" (US Department of Education, 2017, para. 1), both child and family can begin to excel with less doubt. Family support should be a goal of any and all education programs (Alliance for Early Success, 2019).

A possible collaboration for assessment with medical staff for children at risk, can give those with needed medical services more crucial support. "Section 504 eligibility results in the provision of a free appropriate public education (FAPE) to students and qualified adults with disabilities..." (Schuler, 2007, 2010, p.3). This medical support will prevent a rift in communication and support of families in their children's growth \& development. "There's often a rift in communication between educators and parents who suspect their kids have special needs" (Eicher, 2018, para. 1). Although, section 504 gives schools funding needed to service the medical needs of students, there is still a lack of "Team Work" between medical staff and educational staff. Medical needs have proven to impact the assessment qualities of many children.

By assessing the surrounding communities and local small businesses of each school, educational professionals can become familiar with local needs. Knowing the local needs of the community specifics that may not be answered, can begin to give educators a better understanding of each child's needs. For example, knowing that a community is struggling with homelessness, the right supports can be put into place. "Supporting teaching and learning requires addressing students' social service needs, as well as their academic ones, and this broad-based support is essential to closing achievement gaps" (NEA, 2008, p. 1). By closing education gaps, all children will come closer to educational success. "Family and community 
involvements foster partnerships among schools, family and community groups, and individuals. These partnerships result in sharing and maximizing resources" (NHDE, 2012. para. 4).

\section{Teacher Effectiveness}

Teacher effectiveness is also a variable in assessment improvement. In teacher effectiveness, "Research consistently shows that teaching is the single most important school-based factor in a student's academic growth" (Harvard College, 2019, para. 1), thus creating a need to assess teacher effectiveness not only with the use of gathering information from student assessment, but with the culmination of other factors. "Effective teachers have become good at what they do because they evaluate their practice" (Flinders University, n.d. para. 2). Administration observational assessment, parent evaluation, as well as student assessment combined, can give an aggregate score or rating, that can lead to a plan to implement for improvement. "At the end of a school year, there are so many measurements which could indicate that a teacher was "effective"... graduation rates, grades, test scores", etc. Whether a teacher was effective must definitely be measured by how much" each "students' learning increased over a period of time, but it cannot be the only measurement" (Aguilar, 2011, para. 1).

\section{ASSESSMENT RESULTS SHOULD SHOW}

Assessment results if done accurately, will show what improvements need to be made. The results could show information that was not clearly identifiable before the assessment was implemented. A complete assessment will include assessment results of each student, teacher, administrator, environment, community outreach, curriculums, programs and possible other identifiers.

Every school in America will have identical formats of assessments and record keeping, creating a valid outcome. Then, each school should place their assessment results into a national database where the results can be allocated to each person who enters data requests to answer specific questions. For example, a request of ranking with school comparison, or rankings as a list, can be gleaned from this data-base. Another example could glean individual students, or a school building with-in one or more districts. The gleaning mix is almost unlimited. The information gleaned from this data base, especially once built-up with several years of information, can demonstrate a true comparison to our international standings. As of this current date of ending 2020, the American international education standings are based on non-valid scores (Weingarten, 2014). These non-valid scores can create an inaccurate representation of the American educational system.

\section{IMPROVEMENT BASED ON ASSESSMENT RESULTS AND CONCLUSIONS}

Of course, using the results to make student comparisons, school comparisons, racial comparisons, gender, district, state, and other comparisons, will be very helpful in planning and implementing any improvement plans. Below are suggestions in implementing a complete improvement plan with steps that should be taken to implement needed improvement (see Table 1).

The first suggestion is comprised of an objective mentoring program between schools. Schools showing excellence in any area should be paired with a school needing assistance to mentor in that one area of needed improvement. "The first step anyone thinking about starting a mentoring program should take is to define what the objective of the program will be" (Kessler, n.d., para. 1). A mentoring program will help to create a team working atmosphere of education that has not yet been experienced in America. The rewards can prove to be endless, with great success that will include a stipend type scholarship for the schools who qualify and participate in acting as the mentoring school.

A suggestion for the mentoring program, is to have complete measurable objectives for the mentee school to work on, with the assistance of the mentoring school, including a completion date as part of the objective(s). According to Kessler (2020), "Starting a mentoring program might be the closest you'll ever get to making a business decision that has exclusively positive impact" (para. 1). 
TABLE 1

IMPROVEMENT PLAN SUGGESTIONS WITH STEPS (SIMPLIFIED)

\begin{tabular}{|c|c|c|c|c|}
\hline $\begin{array}{c}\text { Suggestion in } \\
\text { order of operation }\end{array}$ & Step 1 & & Step 2 & Step 3 \\
\hline $\begin{array}{l}\text { Federal Funds } \\
\text { Disbursement }\end{array}$ & $\begin{array}{l}\text { Infer direction from } \\
\text { law makers, financial } \\
\text { experts, education } \\
\text { researchers and } \\
\text { practitioners } \\
\text { (educators) }\end{array}$ & 2. & $\begin{array}{l}\text { Create new } \\
\text { National Fund } \\
\text { reserve for } \\
\text { education } \\
\text { Dismantle state } \\
\text { fund reserves } \\
\text { into the } \\
\text { national fund } \\
\text { reserve } \\
\text { Plan National } \\
\text { fund } \\
\text { disbursement } \\
\text { based on } \\
\text { number of } \\
\text { children's } \\
\text { residency's }+ \\
\text { homeless } \\
\text { estimate } \\
\text { (Homeless } \\
\text { have school } \\
\text { choice) }\end{array}$ & $\begin{array}{l}\text { Create and implement a } \\
\text { sequenced plan that will } \\
\text { provide for funds disbursement } \\
\text { equally per student nationwide } \\
\text { with following details } \\
\text { 1. Extra funds towards } \\
\text { special needs } \\
\text { requirements (Ie IEP's, } \\
\text { 504's, ELL's) }\end{array}$ \\
\hline $\begin{array}{c}\text { Assessment Funds } \\
\text { Disbursement }\end{array}$ & $\begin{array}{l}\text { Infer direction from } \\
\text { law makers, financial } \\
\text { experts, education } \\
\text { researchers and } \\
\text { practitioners } \\
\text { (educators) }\end{array}$ & 2. & $\begin{array}{l}\text { Assess } \\
\text { financial needs } \\
\text { of assessment } \\
\text { and } \\
\text { improvement } \\
\text { needed based } \\
\text { on assessment } \\
\text { results } \\
\text { Assign } \\
\text { financial } \\
\text { oversight to } \\
\text { non-partisan } \\
\text { party }\end{array}$ & $\begin{array}{l}\text { 1. Implement funds } \\
\text { disbursement based on } \\
\text { financial report need } \\
\text { for assessment and } \\
\text { improvement plan } \\
\text { 2. This can include but } \\
\text { not limited to: Teacher } \\
\text { training, school } \\
\text { supplies, building } \\
\text { construction and } \\
\text { improvement, etc }\end{array}$ \\
\hline $\begin{array}{c}\text { Valid Testing \& } \\
\text { Assessment of } \\
\text { students }\end{array}$ & $\begin{array}{l}\text { Infer direction from } \\
\text { law makers, } \\
\text { education researchers } \\
\text { and practitioners } \\
\text { (educators) }\end{array}$ & \multicolumn{2}{|c|}{$\begin{array}{l}\text { Decide on valid } \\
\text { Nation-wide } \\
\text { assessment format(s) } \\
\text { for every grade level } \\
\text { from birth (child care) } \\
\text { through senior year } \\
\text { high school }\end{array}$} & $\begin{array}{l}\text { Create a sequenced \& cyclical } \\
\text { plan for implementation that } \\
\text { includes } \\
\text { 1. Nationwide training } \\
\text { for testers, teachers, } \\
\text { administers and other } \\
\text { stake holders } \\
\text { 2. Alignment steps } \\
\text { between grade levels }\end{array}$ \\
\hline
\end{tabular}




\begin{tabular}{|c|c|c|c|}
\hline $\begin{array}{l}\text { Valid Assessments } \\
\text { Non-student }\end{array}$ & $\begin{array}{l}\text { Infer direction from } \\
\text { law makers, } \\
\text { education } \\
\text { researchers and } \\
\text { practitioners } \\
\text { (educators) }\end{array}$ & 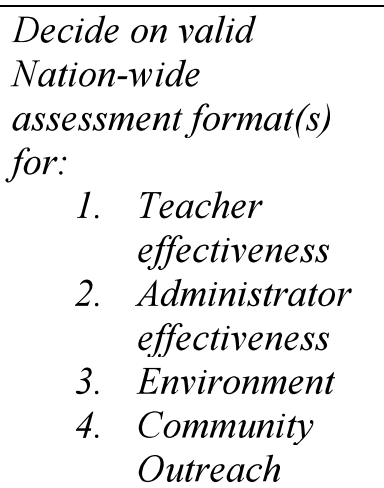 & $\begin{array}{l}\text { Create a sequenced \& cyclical } \\
\text { plan for implementation of } \\
\text { assessment }\end{array}$ \\
\hline $\begin{array}{l}\text { Valid Assessment } \\
\text { Program } \\
\text { Effectiveness }\end{array}$ & $\begin{array}{l}\text { Infer direction from } \\
\text { law makers, } \\
\text { education researchers } \\
\text { and practitioners } \\
\text { (educators) }\end{array}$ & $\begin{array}{l}\text { Decide on format of } \\
\text { program assessment } \\
\text { based on the results of } \\
\text { Valid Assessments } \\
\text { Non-Student }\end{array}$ & $\begin{array}{l}\text { Create a sequenced \& cyclical } \\
\text { plan for implementation of } \\
\text { Valid Assessment Program } \\
\text { Effectiveness }\end{array}$ \\
\hline $\begin{array}{l}\text { Objective } \\
\text { Mentoring }\end{array}$ & $\begin{array}{l}\text { Create \& use } \\
\text { alignment National } \\
\text { data base } \\
\begin{array}{ll}\text { 1. } & \text { Pair } \\
& \text { excelling } \\
\text { program with } \\
\text { challenged } \\
\text { program }\end{array}\end{array}$ & 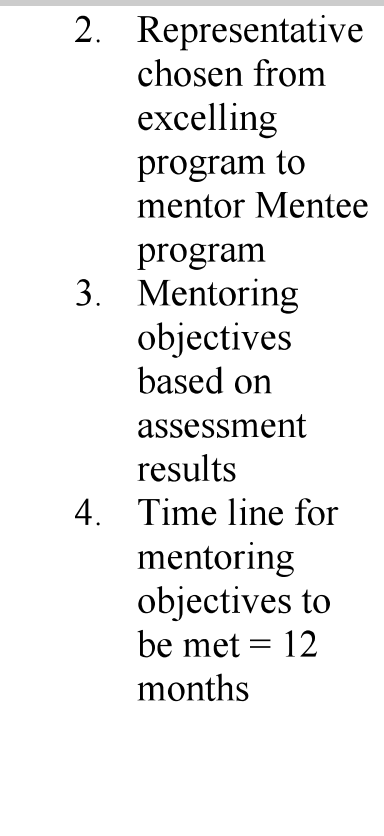 & 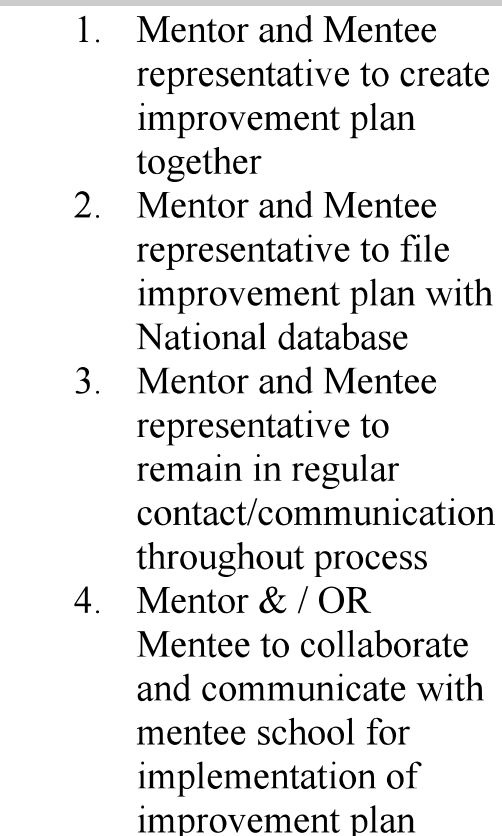 \\
\hline $\begin{array}{l}\text { Follow assessment } \\
\text { - improvement } \\
\text { cycle }\end{array}$ & $\begin{array}{l}\text { Mentee must follow } \\
\text { through with plan } \\
\text { created for } \\
\text { improvement }\end{array}$ & $\begin{array}{l}\text { 1. } \begin{array}{l}\text { Communicate } \\
\text { with all stake } \\
\text { holders }\end{array} \\
\text { 2. Delegate } \\
\text { responsibilities } \\
\text { to members of } \\
\text { educational } \\
\text { staff, } \\
\text { administration, } \\
\text { etc } \\
\text { 3mplement } \\
\text { improvement } \\
\text { plan }\end{array}$ & $\begin{array}{l}\text { 4. With all stake holders, } \\
\text { create a schedule for } \\
\text { planned } \\
\text { implementation - } \\
\text { including completion } \\
\text { date and reassessment } \\
\text { date } \\
\text { 5. Reassess same } \\
\text { variables }\end{array}$ \\
\hline
\end{tabular}


Schools needing improvements need to have a financial assessment complete to determine what funding is needed and where those funds need to be spent, to ensure the needed improvements based on the assessment results. Once the financial need is assessed and finances are dispersed, the assessment result improvements must be aligned with the original assessment objectives and met objectives. This can include: student assessment collected to assess the program as a whole, (Texas education Agency, 2007-2019), what training \& support parents and educators need, curriculum, student assessment, and any other items the assessment has discovered as needed.

Any and all assessment results, improvements to be made, improvements and any recordable objectives, improvements and solutions, need to be shared with all stakeholders including families of school children, and the community at large. "Sharing results centers on the family's concerns, priorities and needs in terms that the family will understand... Families must have information they can understand to make decisions and actively participate in conversations concerning their child and family" (John's Hopkins University, 2011, para. 3). Another suggestion is training parents. Training parents to assist in educating their children can help in the ultimate success of the program, and of the children. Programs need to be required to show documentation of plans and implementation for parent involvement and training, then have documentation of carrying out their efforts of family participation.

We must also consider any training and support teachers need- Educational research is a continuous cycle of new information (Department of Early Education and Care, 2014). This new information needs to be presented to the teaching staff on a regular basis to help support their knowledge base. Although, there may not be enough research that can assist in how to use children's assessments to create a teacher training plan (Department of Early Education and Care, 2014), training is thought to be important. It is vital to "Identify the strengths and weaknesses within a program and information on how well the program meets the goals and needs of the children" (Department of Education and Care, 2014, para. 6).

Implementation of the teacher's training can include stake holders including those from local small business', college professors, center trainers, and others who may be able to assist. For example, a police officer can help to train teachers how to keep children safe during an active shooter alert. Each school needs to have a continuous flow of research that contains what local resources are available for such trainings.

Using assessment improvement techniques described here will ensure the following of Title I legal requirements. "Title I is designed to provide all children significant opportunity to receive a fair, equitable, and high-quality education, and to close educational achievement gaps. (ESEA section 1001)" (Department of Education, 2016, p. 1).

\section{REFERENCES}

Aguilar, E. (2011). Measuring a Teacher's Effectiveness Goes Beyond Test Scores. George Lucas Educational Foundation. Retrieved from https://www.edutopia.org/blog/teacher-effectivenessmeasuring-test-scores-elena-aguilar

Alber, R. (2017). 3 Ways Student Data Can Inform Your Teaching. George Lucas Educational Foundation. Retrieved from https://www.edutopia.org/blog/using-student-data-inform-teachingrebecca-alber

Alliance for Early Success. (2019). Family Support. Retrieved from http://www.earlysuccess.org/resources/family-support

Cambridge Assessment. (2020). Accuracy and reliability - an evidence-based approach. Retrieved from https://www.cambridgeenglish.org/research-and-validation/validity-and-validation/

Department of Early Education and Care. (2014). Early Childhood Assessment. WGBH Educational Foundation. Retrieved from http://resourcesforearlylearning.org/fm/early-childhood-assessment/

Department of Education. (2016). Non-regulatory Guidance. Retrieved from https://www2.ed.gov/policy/elsec/leg/essa/essaswpguidance9192016.pdf

Department of Education and Early Childhood Development. (2014). No English Don't Panic. Retrieved from 
https://www.education.vic.gov.au/Documents/school/teachers/teachingresources/diversity/eal/no_ english_dont_panic.pdf

Eicher, S. (2018). Supporting Parents of Students with Special Needs. George Lucas Educational Foundation. Retrieved from https://www.edutopia.org/article/supporting-parents-students-specialneeds

Flinders University. (n.d.). Teaching Effectiveness. Retrieved from https://www.flinders.edu.au/teaching/quality/evaluation/teaching-effectiveness.cfm

Frankfort International School. (n.d.). Assessing ESL students in the subject classroom. Retrieved from $\mathrm{http}: / /$ esl.fis.edu/teachers/support/eslAssess.htm

Frye, K. (2015). Can the Common Core Counter Educational Inequity? International Legal Lessons on Closing the Achievement Gap. Indiana International \& Comparative Law Review, 25(3), 493540. https://doi.org/10.18060/7909.0029

Gryphon House. (2016). Supporting Families with Special Needs. Retrieved from https://www.gryphonhouse.com/resources/supporting-families-with-special-needs

Harvard College. (2019). Center for Education and Policy Research. Harvard University. Retrieved from https://cepr.harvard.edu/teacher-effectiveness

Illinois Healthcare and Family Services. (2019). Screening, Assessment and Support Services. Retrieved from https://www.illinois.gov/hfs/MedicalProviders/behavioral/sass/Pages/sasshome.aspx

Johns Hopkins University School of Education. (2011). Birth - Five Evaluation and Assessment Model (para. 3). Retrieved from http://olms.cte.jhu.edu/olms2/220615

Kendall, S., Rodger, J., \& Palmer, H. (2010). The use of whole family assessment to identify the needs of families with multiple problems- Research Report DFE-RR045. Retrieved from https://assets.publishing.service.gov.uk/government/uploads/system/uploads/attachment_data/file/ 181688/DFE-RR045.pdf

Kessler, S. (2020). How to Start a Mentoring Program. Retrieved from https://www.inc.com/guides/2010/04/start-mentoring-program.html

Knauf, H. (2017). Documentation as a tool for participation in German early childhood education and care. European Early Childhood Education Research Journal, 25(1), 19-35. https://doi.org/10.1080/1350293X.2015.1102403

Library of Congress. (2019-2020). H.R.1109 - Mental Health Services for Students Act of 2019. Retrieved from https://www.congress.gov/bill/116th-congress/house-bill/1109/actions

Marin, M.A. (2015). Dissertation: Determining the Academic Achievement of English Language Learners (ELLs) by Using Additional Measures of Growth. University of Southern Mississippi. Retrieved from: https://aquila.usm.edu/cgi/viewcontent.cgi?article=1130\&context=dissertations

Mitchell, B.M., \& Salsbury, R.E. (2002). Unequal opportunity: A Crisis in America's Schools? Retrieved from https://search.proquest.com

Montenegro, E., \& Jankowski, N.A. (2017, January). Equity and assessment: Moving towards culturally responsive assessment (Occasional Paper No. 29). Urbana, IL: University of Illinois and Indiana University, National Institute for Learning Outcomes Assessment (NILOA).

Murphy, A.F., \& Torff, B.A. (2014). Standards and Accountability in Conflict. Delta Kappa Gamma Bulletin, 80(4), 19-22.

National Center for Education Statistics (NCES). (2020). Retrieved from https://nces.ed.gov/programs/coe/indicator_cma.asp

National Education Association (NEA). (n.d.). Parent, Family, Community Involvement in Education. Retrieved June 29, 2020, from https://www.nea.org/assets/docs/PB11_ParentInvolvement08.pdf

New Hampshire Department of Education (NHDE). (2012). Why Family and Community Involvement is Important. Retrieved from

https://www.education.nh.gov/instruction/school_health/health_coord_family.htm

Reynolds, R.J. (2012). A Phenomenological Case Study: Teacher Bias Effects on Early Education Assessments. ProQuest LLC. 
Robb, L. (2019). What is Differentiation Instruction? Scholastic Inc. Retrieved from https://www.scholastic.com/teachers/articles/teaching-content/what-differentiated-instruction/

Schuler, D. (2007, 2010). Township Highschool District 214. Retrieved from https://www.d214.org/assets/1/6/11957.PDF

Texas Education Agency. (2007-2019). The Independent Evaluation of the Validity and Reliability of the State of Texas Assessments of Academic Readiness (STAAR) Assessments in grades 3-8, Parts 1 and 2. Executive Summary. Retrieved from https://r.search.yahoo.com/_ylt=AwrJ7Jb7vj5f07kAvx5XNyoA;_ylu=X3oDMTEycTIyNmpzBG NvbG8DYmYxBHBvcwMyBHZ0aWQDQzAxNjRfMQRzZWMDc3I$/ \mathrm{RV}=2 / \mathrm{RE}=1597976443 / \mathrm{RO}=10 / \mathrm{RU}=\mathrm{https} \% 3 \mathrm{a} \% 2 \mathrm{f} \% 2 \mathrm{ftea}$.texas.gov\%2fWorkArea\%2flinkit.asp

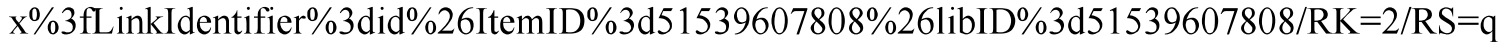
X3wYpPSR1CMIhDspG3Un104QXY-

United States Department of Education. (2008). Structure of US Education: Evaluation and Assessment. Retrieved from https://www2.ed.gov/about/inits/ed/earlylearning/inclusion/resources-forfamilies.html

University of California. (2008). Graduate school of Education \& Information Studies. Retrieved from https://www.brown.edu/academics/education-alliance/teaching-diverselearners/sites/brown.edu.academics.education-alliance.teaching-diverselearners/files/uploads/r737.pdf

University of Nebraska. (1990). Standards for Teacher Competence In Educational Assessments for Students. Retrieved from https://buros.org/standards-teacher-competence-educational-assessmentstudents

US Department of Education. (2017). Early Learning: Inclusion, Resources for Families. Retrieved from https://www2.ed.gov/about/inits/ed/earlylearning/inclusion/resources-for-families.html

US Department of Education. (2019). National Assessment of Educational Progress. Scale Scores and NAEP Achievement Levels. Scale Scores. Retrieved from https://nces.ed.gov/nationsreportcard/guides/scores_achv.aspx

US Department of Education. (2019). Proprietary Schools, Foreign Schools, and Third Party Servicer Audits. Retrieved from https://www2.ed.gov/about/offices/list/oig/nonfed/proprietary.html

Viswanathan, M., Berkman, N.D., Dryden, D.M., \& Hartling, L. (2013, August). Assessing Risk of Bias and Confounding in Observational Studies of Interventions or Exposures: Further Development of the RTI Item Bank [Internet]. Rockville (MD): Agency for Healthcare Research and Quality (US). Appendix A, Approaches to Assessing the Risk of Bias in Studies. Retrieved from https://www.ncbi.nlm.nih.gov/books/NBK154465/

Weingarten, R. (2014). International Education Comparisons: How American Education Reform Is the New Status Quo. New England Journal of Public Policy, 26(1), 1-10.

Wilang, J.D., \& Singhasiri, W. (2017). Out-of-class anxiety in a non-English speaking context and its effects on intelligibility and comprehensibility. Issues in Educational Research, 27(3), 620-638 